\title{
Embalagem ativa para brócolis minimamente processado utilizando 1-metilciclopropeno em sachê biodegradável
}

\author{
Active packaging for fresh-cut broccoli using \\ 1-methylcyclopropene in biodegradable sachet ${ }^{1}$
}

\author{
Fabio Yamashita*; Aline Nunes Matias; Maria Victoria Eiras Grossmann; \\ Sergio Ruffo Roberto; Marta de Toledo Benassi
}

\section{Resumo}

Brócolis minimamente processados foram embalados em bandejas de polipropileno com sachê contendo 1-metilciclopropeno (1-MCP) e selado com filme biodegradável de amido. Os brócolis foram armazenados por 8 dias a $12^{\circ} \mathrm{C}$ e após este tempo a cor e a textura mantiveram-se similares às do produto fresco, sem desenvolvimento de odor não característico ou podridão. A embalagem ativa contendo 1-MCP na forma de sachê foi eficiente no aumento da vida de prateleira de brócolis, retardando o amarelecimento e a perda de vitamina C. Esta é uma alternativa para o tratamento com 1-MCP para produtos minimamente processados e além disso, o sachê pode absorver a água condensada, reduzindo a deterioração e o desenvolvimento de odor não característico.

Palavras-chave: Biofilme, amido, processamento mínimo, hortaliça.

\begin{abstract}
Fresh-cut broccoli florets were packed in polypropylene pots containing a sachet with 1methylcyclopropene (1-MCP) and sealed with biodegradable starch-based film. Broccoli was stored for 8 days at $12^{\circ} \mathrm{C}$ and after this time the color and the texture of the product were similar of the fresh broccoli, with no off-flavor development or decay. Active packaging with 1-MCP in a sachet was efficient to extent shelf life of broccoli florets retarding yellowing and vitamin $\mathrm{C}$ losses. It is an alternative of 1-MCP treatment for fresh-cut products and besides, the sachet can absorbs condensed water reducing spoilage and off-odor development.
\end{abstract}

Key words: Biofilm, starch, minimally processed, vegetable

1 Parte integrante do projeto de pesquisa do primeiro autor

Prof. Dr., TAM/UEL, CP 6001, 86051-990, Londrina-PR

Químico - UEL alinenunesmatias@yahoo.com.br

4 Prof. Dr., TAM/UEL, CP 6001, 86051-990, Londrina-PR

Prof. Dr., AGRONOMIA/UEL, CP 6001, 86051-990, Londrina-PR

Prof. Dr., TAM/UEL, CP 6001, 86051-990, Londrina-PR

Autor para correspondência 


\section{Introduction}

The demand for fresh-cut or minimally processed fruits and vegetables has grown in the 90's in the developed countries due to busy lifestyles, increased purchasing power and health-conscious trends of consumers (Baldwin et al., 1995). These kind of products are becoming more popular in developing countries where the lost of fresh fruits and vegetables are very high, depend on the product (FAO, 2005). To extend the shelf life of fresh cut products while at the same time maintaining nutritional quality and ensuring safety, suitable packaging is necessary, as active packaging systems, that involve an interaction between the packaging itself with the internal gas atmosphere and the food (Labuza \& Breene, 1989). Another problem is concerned about packaging material that are pollutant, meantime over the last few years there has been a renewed interest in biodegradable plastics and plastics made from annually renewable, natural polymers such as starch (Lawton, 1996; Debeaufort et al., 1998) and so called biofilm. Fresh broccoli (Brassica oleracea L.) has been recommended in the diet for cancer prevention but is a very perishable vegetable due to rapid yellowing of flowers bud, incidence of disease, tissue breakdown and off-flavor development, and ethylene has an important role in these events (Corcuff et al., 1996; Ku \& Wills, 1999). 1-Methylcyclopropene (1$\mathrm{MCP}$ ) has been reported to extend shelf life of several fruits, vegetables and flowers due to its capacity to inhibit ethylene action in various plants tissues but it is necessary to treat the product in a close chamber during 24-48 hours with 1-MCP gas (Blankenship \& Dole, 2003). The goal of our work was to develop an active packaging to fresh cut broccoli using starch based biodegradable film or biofilm. The biofilm was used to seal polypropylene pots with broccoli and to produce sachets containing 1-MCP that could be released directly inside the packaging, to extend the shelf life and to avoid the previous treatment in chambers, that are time consuming and costly.

\section{Material and methods}

\section{Plant material}

Fresh broccoli (Brassica oleracea L. var. italica) was harvest from Experimental Farm at Universidade Estadual de Londrina, Brazil, and immediately transported to the laboratory. The broccoli heads were sorted, cut in $10 \mathrm{~cm}$-stalk florets, dipped in sodium hypochlorite solution (150 ppm / $5 \mathrm{~min}$ ), rinsed and centrifuged with a household spin-drier.

\section{Biofilms and sachets preparation}

Biofilms of $100 \mathrm{~mm}$ thick were prepared by casting employing cassava starch and glycerol as plasticizer, according to Mali et al. (2005). Sachets $(80 \mathrm{~mm} \times 50 \mathrm{~mm})$ were prepared with these films wrapping $10 \mathrm{mg}$ of Smartfresh (Rohm \& Hass Quimica Ltda, São Paulo, Brazil), that contains $0.14 \%$ of 1-MCP, diluted in $5 \mathrm{~g}$ of tapioca starch. Previous tests showed no influence $(p>0.05)$ of higher concentrations of Smartfresh in respiration rates of broccolis.

\section{Packaging and storage treatments}

Broccoli florets $(\sim 100 \mathrm{~g})$ were packaged in $1 \mathrm{~L}$ polypropylene pots with the sachet placed at the bottom and sealed with biofilm. The broccolis were stored at $12^{\circ} \mathrm{C}$ during 8 days. Unpackaged broccolis served as control.

\section{Physical and chemical analysis}

Florets were analyzed every two days to determine vitamin C content (AOAC, 1990), stalk firmness and color difference (DE). The firmness, defined as the peak force of the first compression of the sample, was measured using a texture analyzer (Stable Micro Systems, model TA-XT2i, Surrey, England) with the following compression test parameters: load cell $=50 \mathrm{~kg}$, probe $=50 \mathrm{~mm}$ diameter acrylic cylinder, test speed $=5 \mathrm{~mm} / \mathrm{s}$, distance $=50 \%$ 
of stalk diameter. It was measured 12 samples individually. Color was determined using the CIELAB $\operatorname{system}\left(\mathrm{L}^{*}, \mathrm{a}^{*}, \mathrm{~b}^{*}\right)$ with a Minolta CR-10 colorimeter in four points of the florets and DE was calculated between the color at zero time $(0)$ and time $t$ according to equation 1 (Hutchings, 1999).

$$
\Delta \mathrm{E}=\sqrt{\left(\mathrm{L}^{*}-\mathrm{L}_{0}^{*}\right)^{2}+\left(\mathrm{a}^{*}-\mathrm{a}_{0}^{*}\right)^{2}+\left(\mathrm{b}^{*}-\mathrm{b}_{0}^{*}\right)^{2}}
$$

\section{Respiration rate}

About $100 \mathrm{~g}$ of broccolis florets were placed in a container $(5 \mathrm{~L})$ at $12^{\circ} \mathrm{C}$ and determination of respiration rates was based on capacity of basic solutions reacting with carbon dioxide, according to Jacometti et al. (2003).

\section{Resultsand and discussion}

\section{Respiration rates}

Respiration rates of broccolis florets without packaging (control) was $412 \pm 32 \mathrm{mg} \mathrm{CO} / \mathrm{h} . \mathrm{kg}$ and those of the packed ones was about 3 times lower (128 $\pm 14 \mathrm{mg} \mathrm{CO}_{2} / \mathrm{h} . \mathrm{kg}$ ). Previous tests showed that in broccoli packaged without sachet the rate was $206 \pm 31 \mathrm{mg} \mathrm{CO} /$ h.kg. Packaging without sachet could be considered as a modified atmosphere packaging (MAP) and contributed to reduce respiration rates but with 1-MCP the effect was higher than MAP. The authors did not detected offodor development due to possible anaerobic atmosphere inside de packaging. Jacobsson et al. (2004) did not find difference in smell and flavor of fresh-cut broccoli packaged with three different packaging materials (oriented polypropylene, lowdensity polyethylene containing an ethylene absorbent sachet, and polyvinyl chloride) after 7 days at $10^{\circ} \mathrm{C}$ but the respiration rates was affected by the modified atmosphere inside the packaging.

\section{Vitamin $C$}

Vitamin C content decreased for both treatments along storage (Figure 1) but broccoli florets in active packaging showed higher retention after 8 days, $65 \mathrm{mg} / 100 \mathrm{~g}$, against $33 \mathrm{mg} / 100 \mathrm{~g}$ in the control ones probably due to the modified atmosphere and the 1MCP that reduced the product metabolism and, consequently, the vitamin C degradation (Kader, 1986; Blankenship \& Dole, 2003).

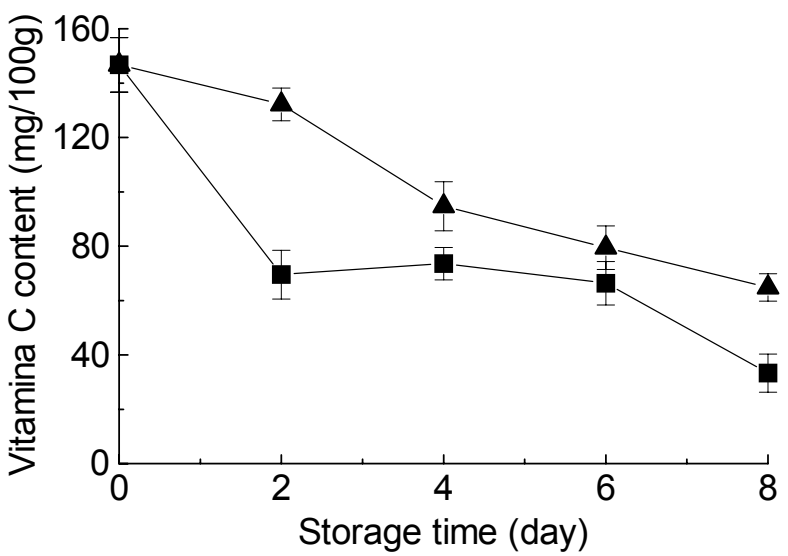

Figure 1. Vitamin $\mathrm{C}$ content of broccolis florets ( $\mathrm{p}$ - active packaging; $\phi$ - control) stored at $12^{\circ} \mathrm{C}$

\section{Firmness}

Stalk firmness were constant for both treatments during storage time (Figure 2) and after 8 days there was no difference with initial time $(\mathrm{p}>0.05)$. According to Brett \& Waldron (1996) in vegetables in which the edible organs are fast-growing immature tissues, maturation often results in toughening. This is due to the continued development of the tissues, particularly those in the early stages of secondary thickening. This broccolis variety did not show stalk softening / hardening with ageing until 8 days and modified atmosphere and 1-MCP had no effect in spite of reducing the respiration rates. 


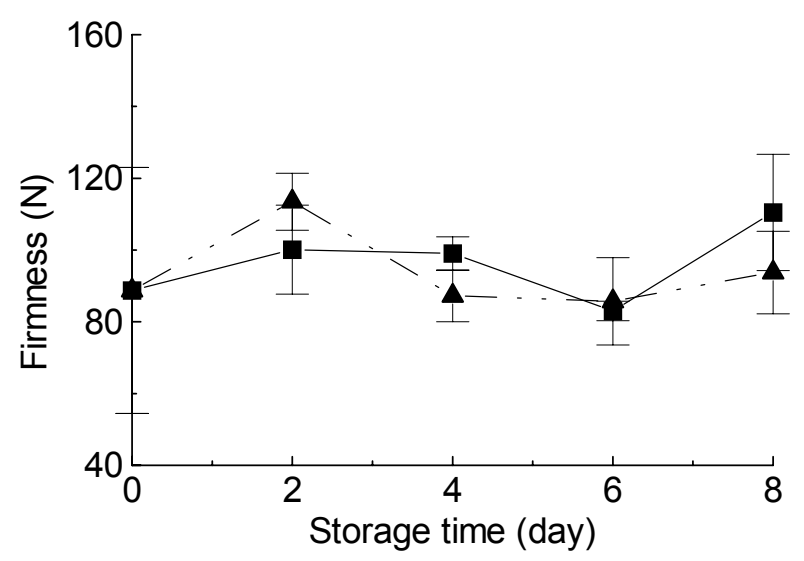

Figure 2. Firmness of broccoli stalks ( $\mathrm{p}$ - active packaging; $\not$-control) during storage at $12^{\circ} \mathrm{C}$

\section{Color}

Packed broccolis preserved original color until the end of storage time with $\mathrm{DE}=1.5$ after 8 days at $12^{\circ} \mathrm{C}$ (Figure 3) probably due to the ethylene antagonist 1MCP. The main cause of deterioration in broccoli is the rapid yellowing of leaves and flowering buds, respectively due to chlorophyll degradation and ethylene appears to have an important role in chlorophyll degradation with exogenous ethylene accelerating this process in a number of brassicas (Wang, 1979; Able et al., 2002). The control florets showed a significant yellowing and after 4 days they were improper to market and at the end of storage time showed $\mathrm{DE}=13.0$.

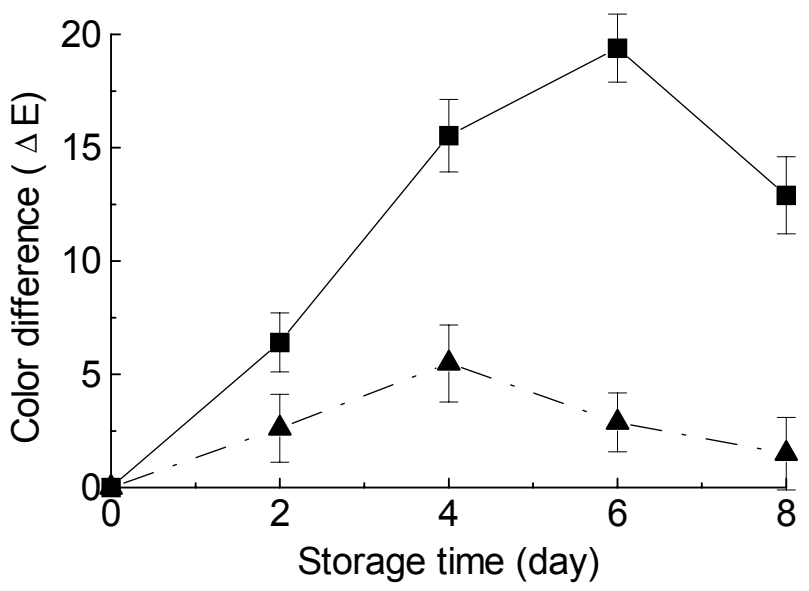

Figure 3. Color difference of broccoli florets (p - active packaging; $\varnothing$ - control) along storage at $12^{\circ} \mathrm{C}$

\section{Conclusion}

Active packaging with 1-MCP in a sachet was efficient to extent shelf life of fresh-cut broccoli florets retarding yellowing and vitamin $\mathrm{C}$ losses. It is an alternative of 1-MCP treatment for several freshcut products and besides, the sachet can absorbs condensed water, necessary to release the gas, reducing spoilage and off-odor development. It is possible to control the 1-MCP release for each commodity modifying the biofilm composition and consequently its vapor water permeability or thickness. Biofilm is an alternative to polyvinyl chloride films used to wrap fresh-cut products, that are pollutant and hard to recycle.

\section{Acknowledgements}

To cnpq for financial support and scholarships and to CAPES for scholarships.

\section{References}

AOAC. Official methods of analysis. 15ed. Arlington: Association of Official Analytical Chemists, 1990.

ABLE, A.J.; WONG, L.S.; PRASAD, A.; O'HARE, T.J. 1MCP is more effective on a floral brassica (Brassica oleracea var. italica L.) than a leafy brassica (Brassica rapa var. chinensis). Postharvest Biology and Technology, v.26, p.147-155, 2002.

BALDWIN, E.A.; NISPEROS-CARRIEDO, M.O.; BAKER, R.A. Use of edible coatings to preserve quality of lightly (and slightly) processed products. Critical Reviews in Food Science and Nutrition, v.35, p.509-524, 1995.

BLANKENSHIP, S.M.; DOLE, J.M. 1Methylcyclopropene: a review. Postharvest Biology and Technology, v.28, p.1-25, 2003.

BRETT, C.T.; WLADRON, K.W. Physiology and biochemistry of plant cell walls. 2.ed. London: Chapman \& Hall, 1996. 245p.

CORCUFF, R.; ARUL, J.; HAMZA, F.; CASTAIGNE, F.; MAKHLOUF, J. Storage of broccoli florets in ethanol vapor enriched atmospheres. Postharvest Biology and Technology, v.7, p.219-229, 1996. 
DEBEAUFORT, F.; QUEZADA-GALLO, J.A.; VOILLEY,A. Edible films and coatings: Tomorrow's packaging: a review. Critical Reviews in Food Science, v.39, p.299-313, 1998.

FAO, 2005.Available in: www.fao.org. Accessed in July 01,2005 .

HUTCHINGS, J.B. Food color and appearance. 2.ed. Gaithersburg: Aspen Publishers, 1999. 610p.

JACOBSSON, A.; NIELSEN, T.; SJÖHOLM. I.; KARIN WENDIN, K. Influence of packaging material and storage condition on the sensory quality of broccoli. Food Quality and Preference, v.15, p.301-310, 2004.

JACOMETTI, G.A.; MENEGHEL, R.F.A.; YAMASHITA, F. Aplicação de revestimentos comestíveis em pêssego (Prunus persica). Ciência e Tecnologia de Alimentos, v.23, p.95-100, 2003.

KADER, A.A. Biochemical and physiological basis for effects of controlled and modified atmospheres on fruits and vegetables. Food Technology, v.40, n.5, p.99-104, 1986.
KU, V.V.V.; WILLS, R.B.H. Effect of 1-methylcyclopropene on the storage life of broccoli. Postharvest Biology and Technology, v.17, p.127-132, 1999.

LABUZA, T.P.; BREENE, W.M. Applications of "active packaging" for improvement of shelf-life and nutritional quality of fresh and extended shelf-life foods. Journal of Food Processing and Preservation, v.13, p.1-69, 1989.

LAWTON, J.W. Effect of starch type on the properties of starch containing films. Carbohydrate Polymers, v.29, 203208, 1996.

MALI, S.; SAKANAKA, L.S.; YAMASHITA, F.; GROSSMANN, M.V.E. Water sorption and mechanical properties of cassava starch films and their relation to plasticizing effect. Carbohydrate Polymers, v.60, p.283$289,2005$.

Wang, C.Y. Effect of short-term carbon dioxide treatment on the market quality of stored broccoli. Journal of Food Science, v.44, p.1478-1482, 1979. 
